\title{
HadGEM2 Küresel İklim Modeli Tahminine Dayalı Konya Kapalı Havzası Olası İçin Tarımsal Kurak Dönemleri
}

\author{
İsmail TAȘ ${ }^{*} \quad$ Yusuf Ersoy YILDIRIM² \\ 'Çanakkale Onsekiz Mart Üni. Ziraat Fak. Tarımsal Yapılar ve Sulama Bölümü. Çanakkale \\ ${ }^{2}$ Ankara Üniversitesi Ziraat Fakültesi Tarımsal Yapılar ve Sulama Bölümü, Ankara
}

\begin{abstract}
*Sorumlu yazar e-mail (Corresponding author e-mail): tas_ismail@yahoo.com
Geliș tarihi (Received) : 05.10.2020

Kabul tarihi (Accepted): 07.10.2020

DOI: $10.21657 /$ topraksu.806184
\end{abstract}

\section{Öz}

Tarımsal kuraklık, bașta canlı hayatı olmak üzere ekonomi ve çevresel sistemler üzerinde ciddi etkiler olușturabilen en tehlikeli doğal afetlerin bașında gelmektedir. Diğer afetlerle karșılaștııılığında kuraklık, yapısı itibari ile belirli farklılıklara sahiptir. Özellikle tarımsal kuraklık doğurduğu ciddi sonuçların yanında büyük maliyetlere de neden olmaktadır. IPCC'nin 2014 yılı raporuna göre, Türkiye senaryosunda gelecekte sıcaklıkların artacağı buna karșıllık yağıșların azalacağı öngörülmektedir. Bu durum dikkate alındığında, ülkemiz genelinde yașanması muhtemel kuraklık afetlerinin süre ve șiddetlerinin artacağı tahmin edilmektedir. Gelecekte yașanması muhtemel tarımsal kuraklık dönemlerinin belirlenmesi bașta sürdürülebilir tarımsal üretimin yanında diğer tüm üretim alanlarını da etkiler. Yapılan bu çalıșmada, Konya Kapalı Havzası için HadGEM2 küresel iklim modelinde "Temsili Konsantrasyon Senaryosunun (Representative Concentration Pathway - RCP)" iyimser (RCP 4.5) ve kötümser (RCP 8.5) koșullarında 2100 yılına kadar tahmin edilen aylık yağıș serilerine Standardize Yağıș İndisi (SPI) uygulanmıștır. Çalıșmalar sonucunda RCP 4.5 senaryosuna göre 4 adet ortak tarımsal kurak dönem (2043-2044, 2046-2047, 2086-2087 ve 2090-2091) belirlenmiștir. RCP 8.5 senaryosuna göre de 5 adet ortak tarımsal kurak dönem (2041-2043, 2060 - 2062, 2072 - 2074, 2092-2094 ve 2095-2097) saptanmıștır. Belirlenen tarımsal kurak dönemlerin havza içerisindeki șiddetlerinin dağılımı, havza șiddet dağılım haritaları ile gösterilmiștir. Konya Kapalı Havzasında yașanması muhtemel tarımsal kurak dönemlerde olușacak su açığına karșı gerekli önlemeler ivedilikle alınmalıdır. Ayrıca, su yönetimi planlarının hazırlanarak tarımsal üretimde kayıplar en aza indirilmelidir. Kuraklık etkilerinin azaltılmasına yönelik alınacak tedbirler, doğrudan bölge üreticisini katkı sağlarken aynı zamanda da ülke üretimi ve ekonomisini de büyük katkılar sağlayacaktır.

Anahtar Kelimeler: Tarımsal Kuraklık, SPI, Sulama Suyu, HadGEM2

\section{Possibil Agricultural Drought Period of Konya Closed Basin Based on HadGEM2 Global Climate Model}

\begin{abstract}
Drought is one of the most dangerous natural disasters that can have serious impacts on the economy and environmental systems, especially on living life. When compared with other disasters, drought has many differences with respect to structure. In particular, agricultural droughts cause great costs as well as serious consequences. According to the IPCC report of 2014, Turkey will increase in the future temperature scenarios rainfall is expected to decrease the contrast. When
\end{abstract}


this situation is taken into consideration, it is estimated that the duration and severity of drought disasters likely to be experienced throughout our country will increase. The determination of agricultural droughts that are likely to occur in the future affects not only sustainable agricultural production but also all other production areas. In this study, the monthly rainfall series estimated up to 2100 under the optimistic (RCP 4.5) and pessimistic (RCP 8.5) conditions of the Representative Concentration Pathway (RCP) in the HadGEM2 global climate model for Konya Closed Basin were used. The obtained monthly rainfall series were analysis with Standardized Precipitation Index (SPI). As a result of the analysis of SPI, it was detected 4 agricultural drought periods (2043-2044, 20462047, 2086-2087 and 2090-2091) for RCP 4.5 scenario. According to RCP 8.5 scenario, it was detected 5 agricultural drought periods (2041-2043, 2060 - 2062, 2072 - 2074, 2092-2094 ve 2095-2097). The severity distribution maps were prepare for the determined agricultural drought periods in the basin. It should be taken precautions in time against the water deficit that will occur in agricultural drought periods which may occur in Konya Closed Basin. In addition, losses in agricultural production should be minimized by preparing water management plans. Measures to be taken to reduce drought effects will directly contribute to the regional producer and contribute to the production and economy of the country.

Keyword: Agricultural drought, SPI, HadGEM2, Irrigation water

\section{GíRiș}

Tarımsal üretim açsından bakıldığında atmosferdeki karbondioksit konsantrasyonunun artıșı ve bitki büyüme mevsiminin uzaması daha fazla verim ve gelir demektir ki bu da arzulanan bir durumdur. Ancak, tarımsal faaliyetlerin tamamı (ekim-dikim, kültürle ișlemler, hasat gibi), așırı hava olaylarının sayısının ve șiddetinin artmasına, sıcaklıkların yükselmesine, yağıș miktarlarındaki ve rejimlerindeki değișimlerden dolayı büyük oranda olumsuz olarak etkilenmektedir. Tarımsal üretim hali hazırda yüz yüze olduğu, artan gıda ve yenilenebilir enerji talepleri nedeniyle büyük olumsuzluklar/güçlükler içindedir. Așırı iklim olaylarının sayısı ve șiddetindeki artıș, çevre kirliliği ve artan su talebi giderek üretimde kaynak sorunlarına yol açacak ve buna bağlı olarakta sürdürülebilir gıda arzı tehlikeye girerek gıda güvenliği için mücadelesi güç büyük bir tehdit olușturacaktır.

Tarım ülkemiz için sadece ekonomik değil aynı zamanda da sosyal olarak önemli bir sektördür. Tarım için genel bir tanımla yapılacak olursa, üstü açık büyük bir fabrika olarak nitelendirilebilir. İklim parametrelerindeki ani değișimler bașta tarım sektörü olmak üzere tüm ekosistemde büyük etkilere yol açmaktadır. Bunun en önemli nedeni, ani değișimlere karșı bitkilerin savunma kabiliyetleri çok yavaș ve sınırlı olmasıdır. Bilim insanları bașta bitki ıslahçıları olmak üzere bitkilerin bu sınırlı savunma kabiliyetlerinin gelișmesi için optimum koșulların olușturulması çabası içerisindedir.
Dünyanın tamamında su kısıtlıı̆ıı, en önemli sorunların bașında yer almaktadır. Yașamdaki tüm faaliyetler az ya da çok suyun miktarı ve kalitesinden etkilenir. Temiz su kaynaklarına olan talebin gün geçtikçe artması beraberinde su kaynağı olarak kullanılabilecek kaynakların dikkatli bir șekilde incelenmesi ve değerlendirilmesini de beraberinde getirmektedir.

Bitkisel üretimde yüksek kalite ve verim için en önemli girdi sulama suyudur. Bitkinin gereksinim duyduğu suyun, intiyaç duyulan zamanda ve miktarda sağlanabilmesi ancak doğru verilerle tasarlanmıș, inșa edilmiș ve ișletilen sistemlerle mümkündür. Sulama yapılarının planlama ve tasarım çalıșmalarının en önemli bileșenlerinden bir tanesi de inșaatın gerçekleștirileceği bölgedeki üretilen ve üretilmesi planlanan bitkilerin su tüketim değerlerinin bilinmesidir. Tasarımda dikkate alınan bitki su tüketim değerlerinin doğruluğu, doğrudan planlama sonuçlarını etkiler (Taș ve Kırnak, 2011 ).

Kuraklık tüm dünyada olduğu gibi $A B D$ 'de de hemen her yıl herhangi bir bölgesinde/ bölgelerinde meydana gelebilmektedir. Ayrıca ciddi ekonomik, sosyal ve çevresel maliyetler yanı sıra önemli mali kayıplarla da neden olmaktadır. Kuraklık olayı ABD'nin yarı kurak bölgelerinin olduğu batı bölgelerinde daha sık meydana gelebilmektedir. Bu bölge 1980'lerin sonlarından 1990'ların bașlarına kadar yoğun șekilde kuraklık yașadı. 1988 yılında ülkenin geniș kesimlerini etkileyen yoğun ve șiddetli kuraklık, tarım ve 
ormancllık bașta olmak üzere ulaștırma, enerji üretimi, su temini, turizm, rekreasyon ve çevre konularında olmak üzere çeșitli sektörlerde ciddi etkiler olușturmuș ve yaklașık 39 milyar dolarlık bir kaybın olușmasına neden olmuștur (Riebsame vd., 1991). Ayrıca, diğer ülkelere yapılan inracatlar azalmıș olup sadece mısır ve buğday inracatından kaynaklanan kayıp 15 milyar dolardan fazla olmuștur. ABD Federal Acil Durum Yönetimi Ajansı (FEMA) 1995 yılında yașanılan kuraklığın maliyetinin yıllık 6-8 milyar dolar civarında olduğunu belirtmektedir (FEMA, 1995). Aynı ajans $1995^{\prime}$ ten bu yana, ülkenin hemen her bölgesinde kuraklıkların meydana geldiğini, bazı bölgelerde birkaç kez ve ardıșık yıllarda tekrarladığını belirtmektedir. ABD’nin doğusunun büyük bölümü 1998-99 yıllarında ciddi bir kuraklık yașamıștır. Ayrıca, güney doğuda bulunan Florida ve Georgia eyaletleri de 1999-2002 arasında ciddi oranda kuraklık yașamıștır (Wilhite vd., 2005).

Kuraklığın belirlenmesinde çok sayıda indis ve indikatör bulunmaktadır. Bunların içerisinde gerek kullanım kolaylığı gerekse yorumlanmasındaki kolaylıklardan dolayı SPI en yaygın kullanılan indislerdendir. Tarımsal kuraklık analizlerinde ise Palmer Nem Anomali İndisi (ZIND) ve SPI analizi en yaygın kullanılanlarındandır. Kolay kullanım ve yorumlanması nedeniyle 6 veya 9 aylık SPI analiz sonuçları tarımsal kuraklık yorumlarında en çok tercih edilen yöntemdir (Gürler, 2017).

Konya Kapalı Havzası iklim koșulları dikkate alındığında, ülkemizde üretimi yapılan ürünlerin büyük bölümünün üretildiği bir bölgedir. Havzada yağıșa dayalı tarım yapılan alanlarda ağırlıkı olarak hububat üretilmektedir. Sulama suyunun bulunabildiği alanlarda ise endüstri bitkileri, sebze ve meyve türleri üretilmektedir. Genel olarak havza Türkiye'nin tahı,, bakliyat ve șekerpancarı ambarı olarak nitelendirilmektedir.

Tarım Orman Bakanlığı́nın Konya Kapalı Havzasında 2019-2024 yılları için yapmıș olduğu Sektörel Su Tahsisi Eylem Planı ve Genelgesine göre, farklı dönemlerde sulama alanlarında ekonomik değeri maksimize edecek șekilde optimum bitki deseni çalıșması yapılmıș ve bu desen için intiyaç duyulan sulama suyu miktarları dönemlere göre belirlenmiștir. Sulama suyu intiyacı, sulama alanı artıșına ve sulama randımanındaki yükselmeye bağlı olarak artıș göstermektedir. Tarım sektörü için hesaplanan su verimliliği değerleri Tablo 1'de verilmiștir. Proje kapsamında farklı dönemlerde sulama alanlarında ekonomik değeri maksimize edecek șekilde optimum bitki deseni çalıșması yapıldığından dönemlere göre sulama alanı miktarı arttıkça ekonomik değer de artmaktadır. Tarım sektöründe YAS ve YÜS dahil toplam 4800 hm³'lük su tahsisi ile olușturulan ekonomik değer 2016 yılında yaklașık 2,16 milyar TL olarak hesaplanırken, bu değerin 2040'da 2.444 hm³'lük su tahsisi ile yaklașık 4,6 milyar TL mertebesine çıkacağı öngörülmektedir (Anonim, 2019).

Yapılan bu çalıșmada, Meteoroloji Genel Müdürlüğü tarafından HadGEM2 küresel iklim modeli kullanılarak RCP 4.5 ve RCP 8.5 iklim senaryolarının çalıștırımasıyla 2100 yııına kadar beklenilen aylık ortalama yağıșlardan 6 aylık SPI analizi yapılarak Konya Kapalı Havzası için 2100 yılına kadarki sürede olasılık dahilindeki tarımsal kurak dönemler belirlenmiștir. Ayrıca belirlenen bu dönemler, kuraklık șiddet toplamları kullanılarak jeoistatistiksel yöntemle alan șiddet dağıım haritalarının üretilmesinde kullanılmıștır.

Çizelge 1. Tarım Sektörü Su Verimliliği $\left(\mathrm{TL} / \mathrm{m}^{3}\right)$

Table 1. Water Efficiency of Agricultural Sector $\left(T \mathrm{~L} / \mathrm{m}^{3}\right)$

\begin{tabular}{cccccccc}
\hline & 2019 & 2020 & 2021 & 2022 & 2023 & 2024 & $2029-2040$ \\
\hline Beyșehir- Çarșamba & 1.41 & 1.46 & 1.51 & 1.54 & 1.68 & 1.73 & 2.11 \\
Konya-Çumra & 0.58 & 0.62 & 0.64 & 0.66 & 0.79 & 0.82 & 1.03 \\
Karaman-Ayrancı & 0.47 & 0.51 & 0.52 & 0.53 & 0.59 & 0.61 & 0.76 \\
Ereğli-Niğde-Bor & 0.75 & 0.84 & 0.87 & 0.89 & 0.98 & 1.02 & 1.27 \\
Aksaray- Sultanhanı & 0.49 & 0.54 & 0.56 & 0.57 & 0.63 & 0.66 & 0.82 \\
Altınekin & 0.47 & 0.49 & 0.51 & 0.52 & 0.57 & 0.60 & 0.74 \\
Cihanbeyli- Yeniceoba & 0.49 & 0.54 & 0.56 & 0.57 & 0.63 & 0.65 & 0.81 \\
Șereflikoçhisar & 0.57 & 0.62 & 0.66 & 0.65 & 0.70 & 0.72 & 0.87 \\
Misli & 0.53 & 0.58 & 0.60 & 0.61 & 0.67 & 0.69 & 0.84 \\
\hline
\end{tabular}




\section{MATERYAL METOT}

\section{Çalıșma alanı ve toprak özellikleri}

Konya Kapalı Havzası; Türkiye'nin İç Anadolu Bölgesi'nde yer alan ve Aksaray, Ankara, Antalya, Isparta, Karaman, Konya, Mersin, Nevșehir ve Niğde illerini tamamını ya da bir kısmını kapsayan bir havzadır. Havza kuzeyden Sakarya ve Kızılırmak, doğudan Kızılırmak ve Seyhan, güneyden Doğu Akdeniz ve batıdan Antalya ve Akarçay Havzaları tarafından çevrelenmektedir. Türkiye'nin yüz ölçümünün yaklașık \%6.4'ünü kaplayan nehir havzasının toplam alanı $49786 \mathrm{~km}^{2}$ dir.

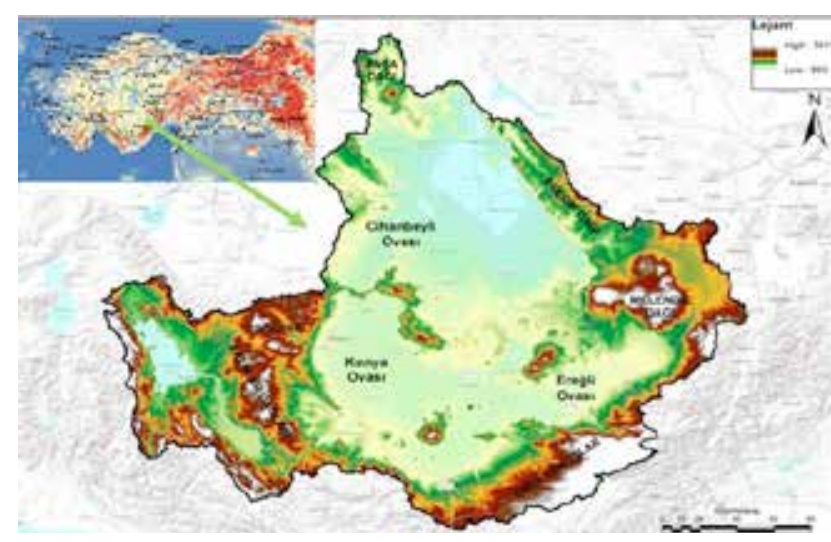

Sekil 1. Konya kapalı havzasının konumu Figure 1. Location of Konya closed basin

DSi verilerine göre bölgede yaklașı 3 milyon ha tarıma elverișli arazi bulunmaktadır. Mevcut su kaynaklarına ilișkin projelerin tamamen geliștirilmesi ve suyun tasarruflu kullanılması koșulunda ancak bu arazinin 1/3'ünden (1.1 milyon ha) biraz fazlasının sulanabilmesi hedeflenmektedir. Tarıma elverișli arazinin tamamen sulanabilmesi için ise en az 7 milyar $\mathrm{m}^{3}$ daha suya intiyaç duyulmaktadır. Bu nedenle havza için hazırlanan raporların büyük bölümünde bölgede yapılacak sulu tarım faaliyetlerinin mutlaka suya göre yapılması önemi üzerinde durulmaktadır. Konya ovası jeolojik formasyonlara bağlı olarak farklı toprak tiplerine sahiptir. Ovanın güneydoğu ve doğusundaki volkanik kökenli arazi üzerinde kalkersiz kahverengi topraklara; ovanın kuzey ve güneyindeki kalkerli sahalarda kırmızı-kahverengi topraklara rastlanır. Ova tabanında ise akarsuların getirmiș olduğu periyodik karakterli alüvyon üzerine alüvyal topraklar; killi ana materyal üzerinde ise yaygın vertisoller; bataklık sahalarda ise yaygın șekilde hidromorfik alüvyal topraklar sıklıkla yer almaktadır (Anonim, 2012).

\section{Araștırma yerinin iklim özellikleri}

Konya Havzası karasal bir iklime sahiptir. Yazlar sıcak ve kurak olup kıșlar soğuk ve az yağıșlıdır. Gündüz-gece sıcaklık farkı yaz aylarında $22^{\circ} \mathrm{C}$ 'ye kadar ulașır. Ocak ayında en düșük ortalama sıcaklık $-0.1{ }^{\circ} \mathrm{C}$ 'dir (Ćizelge 2). Ortalama en fazla sıcaklık Temmuz ayında $23.3^{\circ} \mathrm{C}$ 'dir. Yağıș açsından havza, heterojen bir yapı sergileyip ortalama 283-766 mm arasında değișim göstermektedir. Havzanın doğusunda $360 \mathrm{~mm}$ düzeyine çıkn ortalama yağıș, havzanın orta bölgelerinde Karapınar çevrelerinde 300 mm'nin altına kadar (284 mm) düșüș göstermektedir (Șekil 2). Havzanın batı bölümünde yer alan Seydișehir ve çevresinde ise 766 mm'ye kadar yükselmektedir. Havza geneli için ortalama yağıș 387 mm olarak kabul edilmektedir.

Çizelge 2. Havzaya ait uzun yıllar ortalama sıcaklık, ortalama toplam yağıs ve ortalama buharlașma miktarları (1975-2011) Table 2. Average temperature, average total precipitation and average evaporation of the basin for Long years (1975-2011)

\begin{tabular}{|c|c|c|c|c|c|c|c|c|c|c|c|c|c|}
\hline İstasyon & \multicolumn{10}{|c|}{ Aylık Ortalama Sicaklık ( ${ }^{\circ} \mathrm{C}$ ) } & $\begin{array}{c}\text { P } \\
\text { (mm/yıl) }\end{array}$ \\
\hline & 1 & 2 & 3 & 4 & 5 & 6 & 7 & 8 & 9 & 10 & 11 & 12 & \\
\hline Aksaray & 0.8 & 1.7 & 6.3 & 12 & 16 & 21 & 24 & 24 & 19 & 13 & 7 & 2.6 & 345 \\
\hline Beyșehir & -0 & 0.6 & 4.8 & 10 & 15 & 19 & 22 & 22 & 18 & 12 & 6 & 1.8 & 489 \\
\hline Cihanbeyli & -0 & 0.7 & 5.2 & 11 & 16 & 20 & 24 & 23 & 18 & 12 & 6 & 1.5 & 321 \\
\hline Ereğli & 0.2 & 1.3 & 6.2 & 12 & 16 & 21 & 24 & 23 & 19 & 13 & 6 & 2 & 306 \\
\hline Karapınar & -0 & 0.5 & 5.1 & 11 & 16 & 20 & 23 & 23 & 18 & 12 & 5 & 1.4 & 284 \\
\hline Konya & 0 & 1 & 5.6 & 11 & 16 & 21 & 24 & 24 & 19 & 13 & 6 & 1.7 & 327 \\
\hline Niğde & -0 & 0.6 & 5.2 & 11 & 15 & 20 & 23 & 23 & 18 & 12 & 6 & 1.7 & 332 \\
\hline Seydișehir & 0.4 & 1.1 & 5.8 & 11 & 16 & 20 & 24 & 24 & 19 & 13 & 7 & 2.3 & 770 \\
\hline Ulukıșla & -2 & -1 & 3.5 & 8.9 & 13 & 18 & 22 & 22 & 17 & 11 & 4 & 0.2 & 318 \\
\hline Ortalama & -0.1 & 0.7 & 5.3 & 10.9 & 15.4 & 20.0 & 23.3 & 23.1 & 18.3 & 12.3 & 5.9 & 1.7 & 388 \\
\hline
\end{tabular}




\section{Araștırma yerinin su kaynakları}

Konya Havzası'nda yer alan akarsuların çoğu havza içindeki kaynak veya göllerden çıkar. Yağıșların düzensizliği ve azlığı sebebiyle akarsuların rejimleri düzensizdir. Kıș ve ilkbahar aylarında akıșa geçen dereler kurak geçen yaz aylarında kurumakta ya da debileri ciddi ölçüde azalmaktadır. Havza'daki önemli akarsular: Çarșamba Çayı, İvriz Çayı, Deliçay, Melendiz Çayı, Uluırmak ve Peçenek Deresi'dir. Konya Havzası'nın kapalı havza olması sebebiyle akarsular ova tabanlarındaki bataklıklarda kaybolur. Tuz Gölü, Çavușçu Gölü, Beyșehir Gölü, Ereğli Ovası'ndaki Akgöl, Hotamıș Bataklığı çevresindeki yükseltilerden kaynağını alan dereler kapalı havza șeklindeki bu alanlara akıș gösterirler. Konya ve Ereğli ovalarının çevresindeki yükseltilerden kaynağını alan dereler ovada kaybolur ve göl olușturmazlar. Konya Havzası́nın en büyük gölleri Tuz Gölü ve Beyșehir Gölü'dür. Havza içerisindeki düzlüklerde çok sayıda küçük kapasiteli obruk gölleri bulunmaktadır. Havza'nın güneydoğu sınırındaki dağların zirvelere yakın yerlerde ise küçük kapasiteli buzul gölleri mevcuttur.

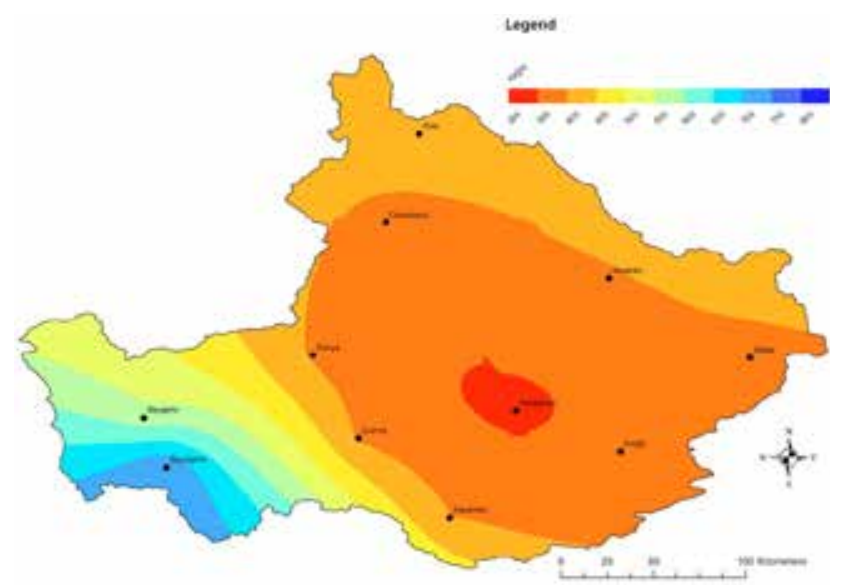

Șekil 2. Konya havzasında yağıșın dağılımı

Figure 2. Distribution of Precipitation in Konya Basin

\section{Küresel iklim modeli}

Çalıșmada, Meteoroloji Genel Müdürlüğünün Hadley Merkezi Küresel Çevre Modeli 2 (HadGEM2) kullanarak elde ettiği yağıș zaman serileri kullanılmıștır. HadGEM2 küresel iklim modeli, ortak bir fiziksel çerçeve ile farklı karmașıkık seviyeleri içeren özel model yapılandırmalarının bir dizisini içermektedir (Demircan vd., 2014). HadGEM2 ailesi, birleștiğinde atmosfer-okyanus yapılandırmasını ve/veya dinamik bitki örtüsü, okyanus biyoloji ve atmosferik kimyasıyla Dünya-Sistem yapılandırması ve iyi bir çözümle stratosferin dâhil olduğu atmosferdeki bir dikey uzantısını içerir. Standart atmosferik bileșeni, $1.875^{\circ}$ boylam ve $1.25^{\circ}$ enlem aralığı ile yatay çözünürlüğünden meydana gelen $192 \times 145$ grid hücresinden olușan küresel bir grid (karelaj) yapısı ve yaklașık 40 km yüksekliğe uzanan 38 seviyeye sahiptir (Demircan vd., 2017).

\section{Tarımsal kuraklığın belirlenmesi}

Bitkinin büyüyüp gelișmesi için gerekli olan suyun kök bölgesinde yeteri kadar bulunmaması tarımsal kuraklığı ifade etmektedir. Özellikle büyüme periyodu boyunca, bitkinin suya en hassas olduğu dönemde bitki için toprakta yeterli nemin olmadığı koșulda tarımsal kuraklık olușmaktadır (Wilhite ve Glantz, 1985).

Toprak nemi koșulları, nispeten kısa bir zaman diliminde yağıș anomalilerine cevap verir. Yeraltı suyu, akarsu ve rezervuar depolama uzun vadeli yağıș anomalilerini yansıtır. Bu nedenle, örneğin, meteorolojik kuraklık için 1 veya 6 aylık bir SPI; tarımsal kuraklık için 1 ila 6 aylık bir SPI ve hidroloji kuraklık için 6 -24 ay (veya daha fazla) SPI analizi iyi sonuçlar verebilir (WMO, 2012). SPI așağıdaki eșitlik I'den yararlanılarak belirlenen zaman dilimi içinde yağıșın ortalamadan olan farkının standart sapmaya bölünmesi ile elde edilir (McKee vd., 1993).

$\widehat{\mathrm{Z}}(\mathrm{X} 0)=\frac{\sum_{i=1}^{N} \mathrm{~W}(\mathrm{Xi}) \mathrm{Z}(\mathrm{Xi})}{\sum_{i=1}^{N} W(X i)}$

Eșitlikte SPI: Standardize Yağıș İndisi; Xi: Mevcut Yağıș; Xj Ortalama Yağıș ve o: standart sapma

SPI analizi kuraklık ve nemlilik sınıflandırmasının sınır değerleri Tablo 3'de gösterilmiștir. Çalıșma kapsamında, kurak dönemler șiddetli kurak ve așırı kurak sınıflar dikkate alınarak belirlenmiștir.

Çizelge 3. SPI Kuraklık/Nemlilik sınıflandırması (McKee vd., 1993) Table 3. SPI Drought / Humidity classification (McKee vd., 1993)

\begin{tabular}{cc} 
Standart Yağıș İndisi & Yağıș (Kuraklık/Nemlilik) Sınıfı \\
\hline 2 ve üzeri & Așırı nemli \\
$1.5-1.99$ & Çok nemli \\
$1-1.49$ & Orta düzeyde nemli \\
$0.5-0.99$ & Normale yakın nemlice \\
$-0.499-0.499$ & Normal \\
$-0.5--0.99$ & Normale yakın kurakça \\
$-1--1.49$ & Orta düzeyde kurak \\
$-1.5--1.99$ & Șiddetli kurak \\
-2 ve altı & Așırı kurak
\end{tabular}


Çalıșmada, havza genelinde etkili olan kurak periyotlar belirlenmiș ve söz konusu periyotlar kurak periyot olarak kabul edilmiștir. Diğer bir ifadeyle dikkate alınan istasyonların kurak dönemlerinin havzadaki diğer istasyonlarla benzerliği dikkate alınmıștır. Noktasal istasyonların kuraklıkları, havzanın genelini yansıtmadığı için dikkate alınmamıștır.

\section{Jeoistatistiksel yöntem}

İstatistiğin uygulamalı bir dalı olan jeoistatistik, ilk defa yerbilimlerinde karșılașılan tahmin problemlerinin çözümüne yönelik olarak kullanılmıștır. Jeoistatistikte ölçüm yapılan notaların konumları ile gözlemler arası korelasyon dikkate alınır. Bu yöntemle yansız ve minimum varyanslı tahminler yapılabilmektedir (Olea, 1977. Bașkan, 2004). ÖIçülen değerlerden deneysel variogram yapısı belirlenir. Jeoistatistiksel çalıșmaların temelini, bu belirlenen variogram yapısına teorik bir modelin uydurulması olușturmaktadır (Delhomme 1978, Vieira vd., 1983, Bașkan, 2004). Jeoistatistiksel yöntemler, yönlü verilere uygulandığında oldukça sağlam ve güçlü sonuçlar ortaya koymaktadır.

Haritaların hazırlanmasında Uzaklığın Tersi ile Ağırlıklandırma (Inverse Distance Weighting - IDW) enterpolasyon yöntemi kullanılmıștır. IDW, enterpolasyon yöntemi olarak iklim parametrelerinin ișlenmesinde kullanılan en yaygın yöntemdir. Yöntemin temeli iki nokta arasındaki ilișkinin ve benzerliğin, aradaki uzaklıkla orantılı olduğu kabulüne dayanır (Aydın ve Çiçek, 2013). Yöntem, araștırılan nokta değerinin yakınındaki bilinen nokta değerlerine daha benzer olacağını kabul etmektedir. Bu varsayımdan yola çıkarak bilinmeyen noktalara yakın olan bilinen noktaların, tahmin edilecek noktanın değeri üzerine daha yüksek etkiye (ağırlığa) sahip olacağı anlașılmaktadır. IDW yönteminde her örnek noktası, değeri tahmin edilecek noktaya olan uzaklığına ters oranda ağırlık değeri almaktadır (Isaaks ve Srivastava, 1989). Diğer bir ifadeyle bilinmeyen noktanın tahmininde; bilinen noktaların yakın olanlarına daha yüksek oranda ağırlığı olurken uzak olanların ise daha düșük bir ağılıkta temsili söz konusudur (Franke ve Nielson, 1980; Kale, 2018). Bu nedenle IDW, bilinmeyen mekansal yağıș verilerini, bilinmeyen bölgeye bitișik yerlerin bilinen verilerinden tahmin etmek için kullanılabilir (Li ve Heap, 2008;
Goovaerts, 2000). IDW formülleri așağıdaki eșitlik 2 de verilmiștir. Ayrıca, yöntemde kullanılan ağılıklandırma eșitlik 3'de verildiği gibidir.

$$
\begin{aligned}
& \hat{\mathrm{Z}}(\mathrm{X} 0)=\frac{\sum_{i=1}^{N} \mathrm{~W}(\mathrm{Xi}) \mathrm{Z}(\mathrm{Xi})}{\sum_{i=1}^{N} W(X i)} \\
& W(\mathrm{Xi})=\left(\frac{1}{d i}\right)^{P}
\end{aligned}
$$

Eșitliklerde; $W(X i)$ i'inci bilinen konumdaki ağırlığı, Z(Xi) i'inci konumdaki bilinen örnek noktası değerini, N ölçüm noktası sayısını, d örnek noktası ve tahmin noktası arasındaki mesafeyi ve $p$ üstel güç katsayısını ifade etmektedir (Ahrens, 2006).

\section{BULGULAR VE TARTIȘMA}

\section{RCP 4.5 İklim senaryosuna göre tarımsal ortak kurak dönemler}

RCP 4.5 İklim senaryosuna göre șiddetli kurak ve așırı kurak sınıflar dikkate alındığında havzada dört adet ortak kurak dönem belirlenmiștir. Bunlar sirasiyla 2043-2044, 2046-2047, 2086-2087 ve 2090-2091 yıllarını kapsamaktadır. En șiddetli ve uzun olanı da 2046-2047 yıllarını kapsayan ortak kurak dönemdir.

\section{3-2044 Tarımsal kurak dönem}

Bu kurak dönem yaklașık iki yıllık süreyi kapsamaktadır. Her bir istasyon için șiddetli ve așırı kurak sınıflar dikkate alınarak tarımsal kuraklık șiddeti hesaplanmıștır. Șekil 3'den de görüleceği gibi, bu tarımsal ortak kurak dönem havza içerisinde dalgalı bir yapı göstermektedir. Havzanın doğusundaki Niğde ve Aksaray çevrelerinde kuraklık șiddet toplamı -35 seviyelerine kadar yükselmektedir. Söz konusu bölgeler, tarımsal kuraklığın bu devre için en șiddetli yașanacağı bölgeler olarak öngörülmektedir. Öte yandan Kulu, Cihanbeyli, Eskil, Emirgazi, Karapınar, Ayrancı ve Karaman çevreleri de büyük ölçekte kuraklık șiddetler toplamı -25 seviyelerine varan bir kuraklığın olușacağı belirlenmiștir. Bu dönemdeki tarımsal kuraklıktan en az etkilenecek bölgeler ise Ereğli, Konya, Dereben, Çumra ve Kayhöyük istasyon çevreleridir. Söz konusu bölgede kuraklık șiddetleri toplamı -10 seviyelerine kadar düșmektedir. 


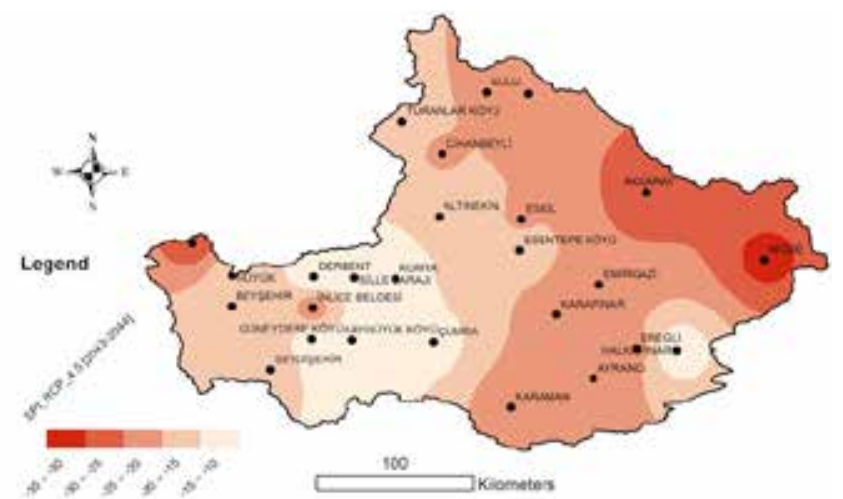

Sekil 3. RCP 4.5 senaryosuna göre 2043-2044 ortak tarımsal kurak dönem

Figure 3. Under the RCP 4.5 scenarios to change in agricultural droght for the 2043-2044 period

\section{6-2047 Tarımsal kurak dönem}

Bu kurak dönem bir önceki dönem gibi yaklașık iki yıl süreceği öngörülmektedir. Her bir istasyon için șiddetli ve așırı kurak sınıflar dikkate alınarak tarımsal kuraklık șiddeti hesaplanmıștır. Șekil 4'den de görüleceği gibi, ortak tarımsal kurak dönem havzaiçerisinde hafif dal galı biryapı göstermektedir. Bir önceki kurak dönemin aksine havzanın doğusundaki Niğde ve Aksaray çevrelerinde daha düșük șiddette (kuraklık șiddet toplamları -15) bir tarımsal kuraklık olușması öngörülmektedir. Havzanın kuzey ve orta kuzey bölgeleri (bașta Altınekin olmak üzere Kulu, Cihanbeyli, Eskil ve Emirgazi) kuraklıktan en fazla etkilenecek bölgeler olarak saptanmıștır. Söz konusu bölgelere kuraklık șiddet toplamı -40 seviyelerine kadar yükselmesi beklenmektedir. Havzanın büyük bölümünde kuraklık șiddeti toplamı -25 seviyesinde tarımsal kuraklık olacağı öngörülmektedir. Kuraklığın en az etkileyeceği alan Beyșehir çevresi olarak saptanmıștır.

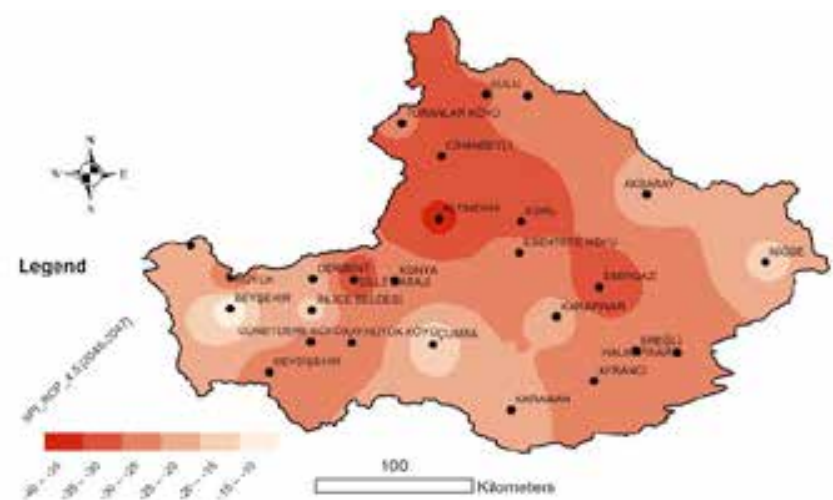

Sekil 4. RCP 4.5 senaryosuna göre 2046-2047 ortak tarımsal kurak dönem

Figure 4. Under the RCP 4.5 scenarios to change in agricultural droght for the 2046-2047 period

\section{6-2087 Tarımsal kurak dönem}

Bu kurak dönem de yaklașık iki yıl süreceği tahmin edilmektedir. Her bir istasyon için șiddetli ve așırı kurak sınıflar dikkate alınarak tarımsal kuraklık șiddeti hesaplanmıștır. Șekil 5'den de görüleceği gibi, ortak tarımsal kurak dönem havza içerisinde kademli bir değișim sergilemektedir.

Havzanın doğusundaki Niğde ve güneyinde yer alan Karapınar, Ereğli, Çumra (Çumra en az etkilenecek bölge) ve Karaman çevreleri yanı sıra Kula ve Dere köy kuraklığın en az etkileyeceği bölgelerdir. Söz konusu bölgelerde kuraklık șiddeti toplamı -15'in altındadır. Buna karșılık Cihanbeyli, Eskil, Konya, Hüyük, ve Seydișehir istasyon çevrelerinde kuraklık șiddet toplamı -30'lara kadar yükselmektedir. Söz konusu bölgeler bu kurak devrede kuraklıktan en fazla etkilenecek alanlar olarak belirlenmiștir. Yukarıda bahsedilen bölgelerin dıșında kalan alanlar da ise kuraklık șiddetleri toplamı -25 'in altında olacak șekilde kuraklıktan etkileneceği öngörülmektedir.

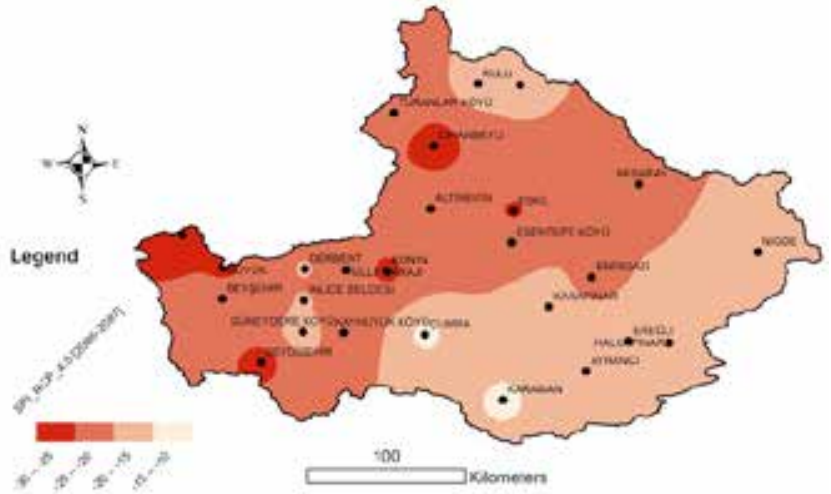

Șekil 5. RCP 4.5 senaryosuna göre 2086-2087 ortak tarımsal kurak dönem

Figure 5. Under the RCP 4.5 scenarios to change in agricultural droght for the 2086-2087 period

\section{0-2091 Tarımsal kurak dönem}

Bu kurak dönem de yaklașık iki yıl süreceği tahmin edilmektedir. Her bir istasyon için șiddetli ve așırı kurak sınıflar dikkate alınarak tarımsal kuraklık șiddeti hesaplanmıștır. Șekil G'dan da görüleceği gibi, ortak tarımsal kurak dönem havza içerisinde hafif bir dalgalı yapı sergilemektedir. Havzanın doğusundaki Niğde ve güneyinde yer alan Ereğli (en fazla etkilenecek bölge) ve Ayrancı çevreleri kuraklığın en fazla etkili olacağı bölgeler olarak belirlenmiștir.

Söz konusu bölgelerde kuraklık șiddeti toplamı -30'lara kadar yükselmektedir. Buna karșilık 
Eskil, Esenetepe köyü ve Karapınar çevreleri anılan bölgelere göre daha az etkilenmesi beklenilmektedir. Anılan bölgelerin kuraklık șiddetleri toplamları -20 seviyesindedir. Bu kuraklık devrede en az etkilenecek bölgeler Aksaray ve Beyșehir çevreleri olacağı öngörülmektedir.

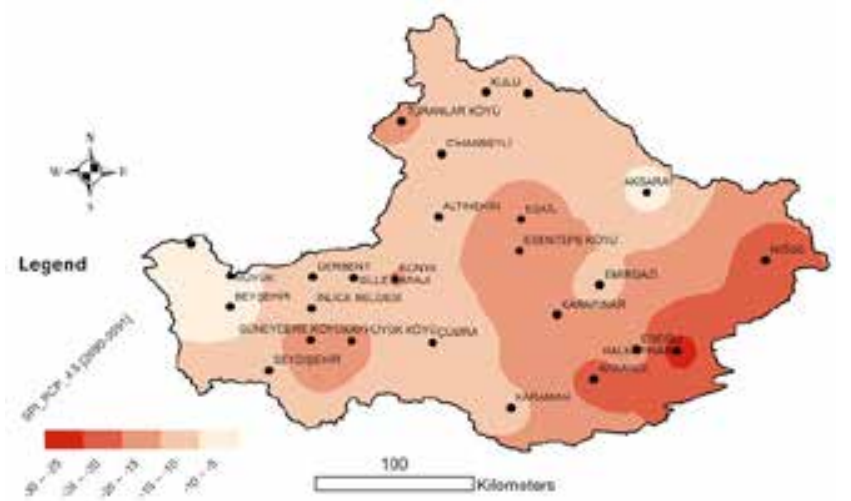

Șekil 6. RCP 4.5 senaryosuna göre 2090-2091 ortak tarımsal kurak dönem

Figure 6. Under the RCP 4.5 scenarios to change in agricultural droght for the 2090-2091 period

\section{RCP 8.5 İklim senaryosuna göre tarımsal ortak kurak dönemler}

RCP 8.5 İlim senaryosuna göre șiddetli kurak ve așırı kurak sınıflar dikkate alındığında havzada beș adet ortak kurak dönem belirlenmiștir. Bunlar sirasiyla 2041-2043, 2060-2062, 2072-2074, 2092-2094 ve 2095-2097 yıllarını kapsamaktadır. En șiddetli olanı da 2072-2074 yıllarını kapsayan ortak kurak dönemdir.

\section{1-2043 Tarımsal kurak dönem}

Bu kurak dönem yaklașık üç yıl süreceği öngörülmektedir. Her bir istasyon için șiddetli ve așırı kurak sınıflar dikkate alınarak tarımsal kuraklık șiddeti hesaplanmıștır. Șekil 7'den de görüleceği gibi, ortak tarımsal kurak dönem havza içerisinde hafif dalgalı bir yapı göstermektedir. Havzanın orta bölümündeki Altınekin, Eskil, Esentepe Köyü, Emirgazi, Karapınar, Halkapınar Karaman ve Ayrancı (en az etkilenecek) bölgeleri olup kuraklık șiddetleri toplamı -15 seviyesindedir. Ereğli, Niğde Aksaray, Cihanbeyli, ve havzanın batı bölümünün büyük bölümünde kuraklık șiddetleri -20 seviyesine kadar yükselmektedir. Tarımsal kuraklığın en fazla hissedileceği bölge Kula ve çevresi (șiddetler toplamı -30) ile Derebent ve Seydișehir (kuraklık șiddet toplamları -25) çevreleridir.

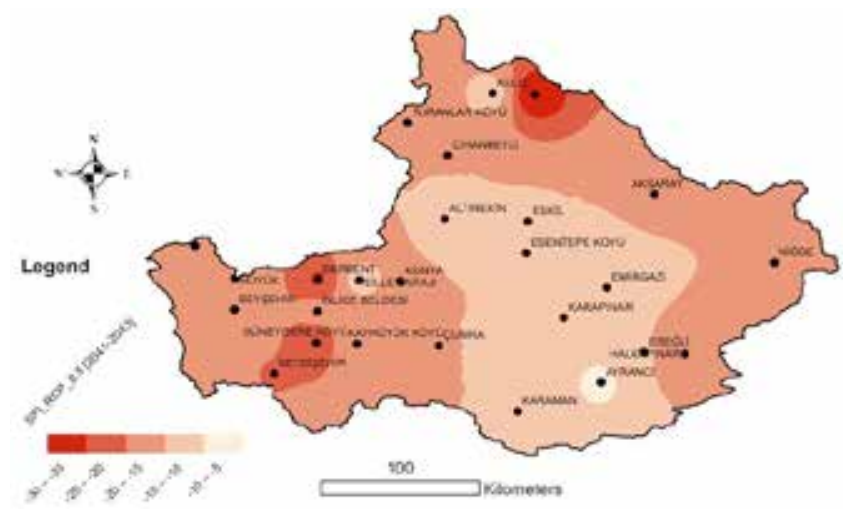

Șekil 7. RCP 8.5 senaryosuna göre 2041-2043 ortak tarımsal kurak dönem

Figure 7. Under the RCP 8.5 scenarios to change in agricultural droght for the 2041-2043 period

\section{0-2062 Tarımsal kurak dönem}

Bu kurak dönemin de yaklașık üç yıl süreceği öngörülmektedir. Her bir istasyon için șiddetli ve așırı kurak sınıflar dikkate alınarak tarımsal kuraklık șiddeti hesaplanmıștır. Șekil 8'den de görüleceği gibi, ortak tarımsal kurak dönem havzanın büyük bölümünde homojen sayılabilecek bir dağıım sergilemektedir. Havzanın kuzeyindeki Kulu ve doğusundaki Niğde istasyonları kuraklığın en șiddetli yașanacağı (șiddetler toplamı -30 seviyesine kadar yükselmektedir) öngörülmektedir. Konya, Derebent, Beyșehir, Seydișehir, Çumra ve Ayrancı istasyon çevreleri havzanın diğer bölgelerine göre kısmen daha az șiddette tarımsal kuraklık yașamaları öngörülmektedir. Öte yandan havzanın diğer kalan bölgelerinde kuraklık șiddet toplamı -15 seviyesinin altında bir tarımsal kuraklık yașaması öngörülmektedir.

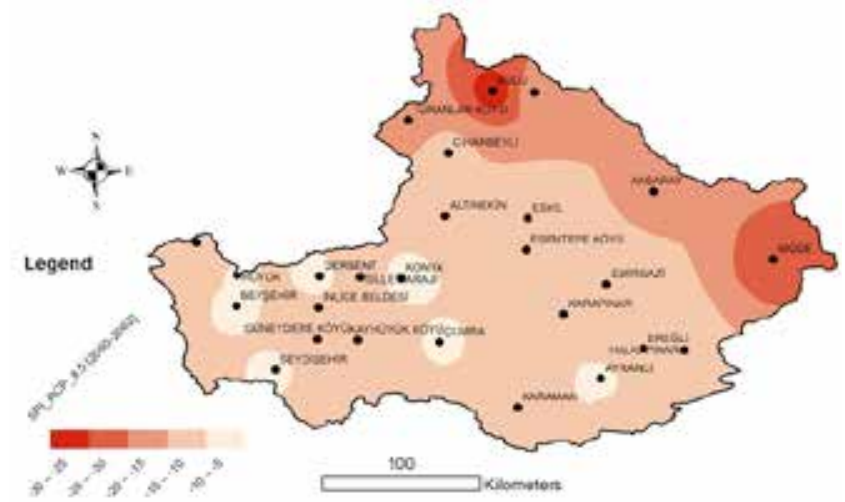

Șekil 8. RCP 8.5 senaryosuna göre 2060-2062 ortak tarımsal kurak dönem

Figure 8. Under the RCP 8.5 scenarios to change in agricultural droght for the 2060-2062 period 


\section{2-2074 Tarımsal kurak dönem}

Bu kurak dönem de diğer kurak periyotlar gibi yaklașık üç yıl süreceği öngörülmektedir. Her bir istasyon için șiddetli ve așırı kurak sınıflar dikkate alınarak tarımsal kuraklık șiddeti hesaplanmıștır. Șekil 9'dan da görüleceği gibi, ortak tarımsal kurak dönem havza içerisinde dalgalı bir yapı göstermektedir. Havzanın güneyindeki Karapınar (en șiddetli), Ayrancı ve Karaman istasyon çevreleri tarımsal kuraklığı en șiddetli seviyede (șiddet toplamı -45 seviyesine kadar yükselmekte) yașayacağı öngörülmektedir. Havzanın doğusunda Niğde ve batı bölümündeki Hüyük, Beyșehir, İnlice Beldesi, Dereköy ve Seydișehir çevreleri tarımsal kuraklıktan diğer bölgelere göre daha az etkileneceklerdir (șiddetler toplamı -15). Havzanın geri kalan bölümünde ise kuraklık șiddet toplamları -30 seviyelerine kadar yükselmektedir.

\section{2-2094 Tarımsal kurak dönem}

Bu kurak dönem de diğer kurak periyotlar gibi yaklașık üç yıl süreceği öngörülmektedir. Her bir istasyon için șiddetli ve așırı kurak sınıflar dikkate alınarak tarımsal kuraklık șiddeti hesaplanmıștır. Sekil 10'dan da görüleceği gibi, ortak tarımsal kurak dönem havza içerisinde kısmen homojen bir dağııı göstermektedir. Havzanın batısındaki Derebent, Sille barajı, Konya, Güneydere köyü, İnlice beldesi ve Seydișehir çevrelerinin yanı sıra Ereğli, Kula ve Turnalar köyü isatasyon çevrelerinde tarımsal kuraklık en fazla etkili olacaktır (șiddetler toplamı-25). Cihanbeyli, Altınekin, Eskil ve Karaman çevreleri tarımsla kuraklıktan en az etkilenecek bölgelerdir (șiddetler toplamı -10). Geriye kalan bölgelerde ise tarımsal kuraklık șiddet toplamları -20 seviyelerinde olușturacağı öngörülmektedir.

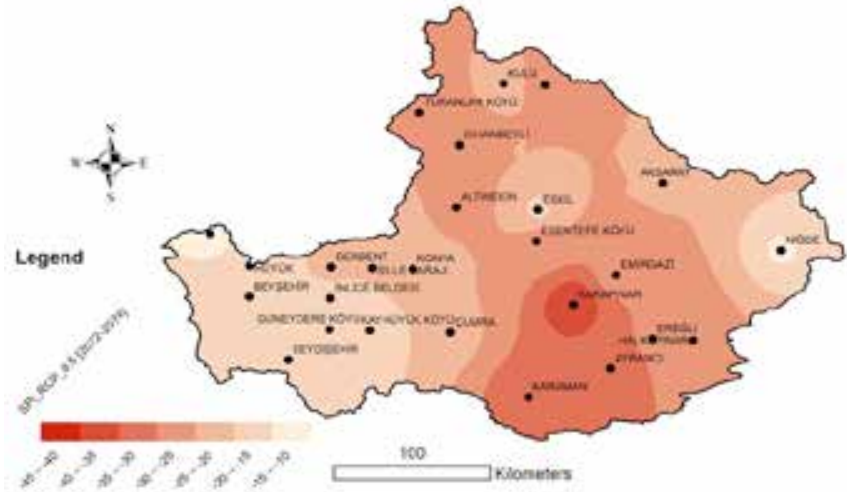

Șekil 9. RCP 8.5 senaryosuna göre 2072-2074 ortak tarımsal kurak dönem

Figure 9. Under the RCP 8.5 scenarios to change in agricultural droght for the 2072-2074 period

\section{5-2097 Tarımsal kurak dönem}

Bu kurak dönem de diğer kurak periyotlar gibi yaklașık üç yıl süreceği öngörülmektedir. Her bir istasyon için șiddetli ve așırı kurak sınıflar dikkate alınarak tarımsal kuraklık șiddeti hesaplanmıștır. Sekil 11'den de görüleceği gibi, ortak tarımsal kurak dönem havza içerisinde hafif dalgalı bir yapı sergilemektedir. Havzanın doğusundaki Niğde, Ereğli'nin yanı sıra özellikle Karaman ve Emirgazi çevrelerinde tarımsal kuraklık șiddet toplamı yaklașık -35 seviyelerine kadar yükselmektedir. Havzanın kuzeyinde yer alan Kulu ve Turnalar köyü çevresinde tarımsal kuraklık șiddeti toplamı -10 seviyesine kadar düșüș göstermektedir. Sayılanların dıșında kalana bölgelerde ise -15 seviyelerine bir kuraklığın olușacağı öngörülmektedir.

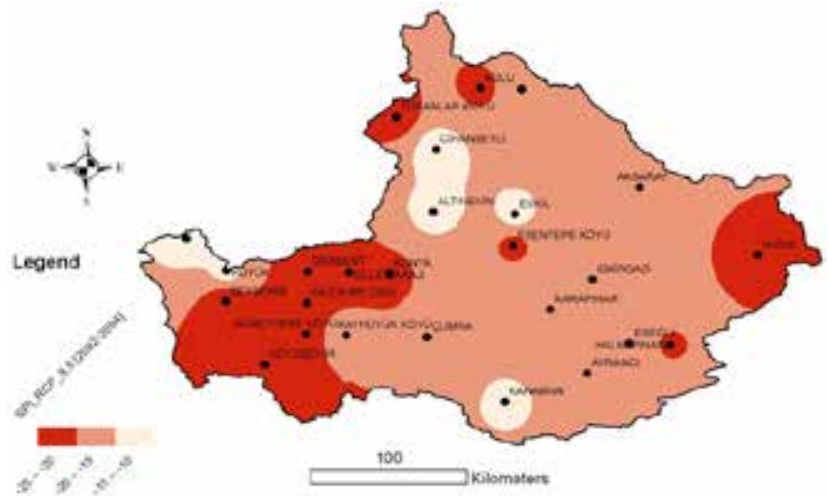

Șekil 1 0. RCP 8.5 senaryosuna göre 2092-2094 ortak tarımsal kurak dönem

Figure 10. Under the RCP 8.5 scenarios to change in agricultural droght for the 2092-2094 period

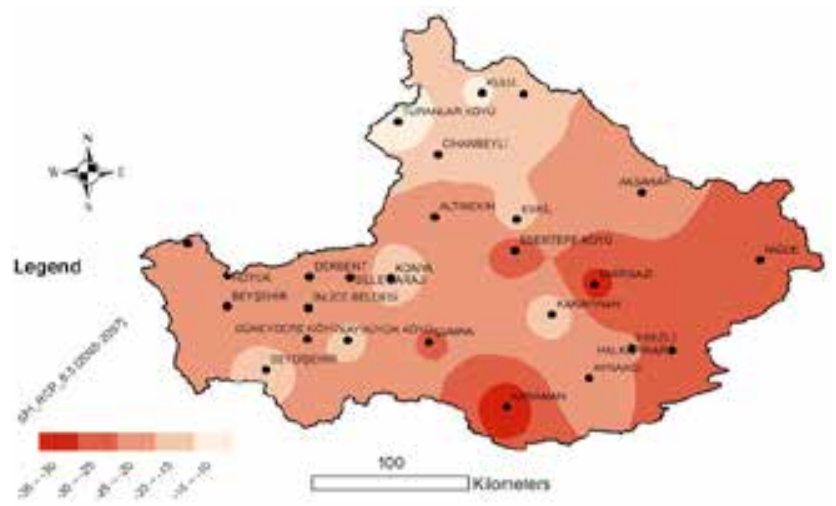

Șekil 11 . RCP 8.5 senaryosuna göre 2095-2097 ortak tarımsal kurak dönem

Figure 11. Under the RCP 8.5 scenarios to change in agricultural droght for the 2095-2097 period

\section{SONUCLAR}

Küresel boyutta iklimsel dalgalanmaların yașandığı günümüzde, yașamın en temel öğesi 
Çizelge 4. Konya Kapalı Havzası Sulama Suyu İhtiyaçları

Table 4. Irrigation Water Requirement of Konya Closed Basin

\begin{tabular}{ccccccccc}
\hline & 2019 & 2020 & 2021 & 2022 & 2023 & 2024 & 2029 & 2040 \\
Sulama Alanı (bin ha) & 900 & 904 & 919 & 928 & 957 & 962 & 970 & 970 \\
Ortalama Randıman \% & 59 & 61 & 63 & 64 & 70 & 72 & 88 & 88 \\
Sulama Suyu İhtiyacı $\left(\mathrm{hm}^{3}\right)$ & 4553 & 4464 & 4644 & 4565 & 4268 & 4160 & 4615 & 4615 \\
\hline
\end{tabular}

olan suyun, deniz, kara ve hava arasındaki çevrim ve bu çevrimde meydana gelen değișikliklerin, ekonomik pek çok sektörde, toplumda ve çevrede önemli ve geniș çaplı etkilere sahip olduğu geniș çevrelerce kabul edilen bir gerçekliktir. Örneğin pek çok kara ve su ekosistemlerinin özellikleri, belirgin bir biçimde suyun mevcudiyeti ile değișkenlik göstermektedir. Su, canlı yașamı faaliyetlerin ayrılmaz bir parçasıdır. Bununla beraber, temiz suyun mevcudiyeti ekonomik kalkınmayı da etkiler. Bunun en çarpıcı örneği tarımdır.

Konya Kapalı Havzası için 2100 yılına kadarki olası ortak tarımsal kurak dönemler belirlenmiștir. RCP 4.5 senaryosuna göre 2043-2044, 20462047, 2086-2087 ve 2090-2091 yılları olmak üzere 4 adet ortak tarımsal kurak dönem saptanmıștır. RCP 8.5'e göre ise 2041-2043, 2060 - 2062, 2072 - 2074, 2092-2094 ve 2095-2097 yılları olmak üzere 5 adet ortak tarımsal kurak periyotlar olarak belirlenmiștir. Bunların dıșında noktasal kurak dönemler zaman zaman olușmakta ancak bunlar havzanın genelini yansıtmadığı için dikkate alınmamıștır.

Tarım Orman Bakanlığı́nın Konya Kapalı Havzası için 2019-2024 yılları için yapmıș olduğu Sektörel Su Tahsisi Eylem Planı ve Genelgesine göre, Konya Kapalı Havzası́nda mevcut durumda 890 bin ha alan sulanmaktadır. Bu alanın 2025 yılına kadar 969 bin ha'ya çıkarılması planlanmaktadır. 2019-2040 döneminde sulama alanı ve ortalama randıman değerlerindeki değișim ve buna bağlı olarak hesaplanan sulama suyu ihtiyaçları așağıdaki Tablo 4'de verildiği șekilde öngörülmüștür (Anonim, 2019). Çalıșma sonunda belirlenen kurak dönemlerde gerek mevcut tarımsal üretimin korunması gerekse yukarıda belirtilen söz konusu planlamaların aksamadan hayata geçirilmesi için șimdiden gerekli çalıșmaların yapııması gerekmektedir.

Çalıșma sonunda belirlenen kurak dönemlerde gerekmevcuttarımsal üretimin korunması, gerekse yukarıda belirtilen söz konusu planlamaların aksamadan hayata geçirilmesi için șimdiden gerekli çalıșmaların yapılması gerekmektedir. Ayrıca gelecekte yapılması planlanan çalıșmalarda her iki senaryo sonuçlarına göre olasılık dahilinde görülen kurak dönemlerin de dikkate alınması sürdürülebilir üretim ve büyüme için önemli katkılar sağlayacaktır. Özellikle yağıșa dayalı tarımın yapıldığı alanlarda toprak neminde meydana gelecek su açığına karșı gerekli tedbirlerin alınması büyük önem arz etmektedir. Belirtilen dönemlerde kuraklığa dayanıklı tür ve çeșitlerin yanı sıra, az sulama suyu intiyacı olan bitkilerin üretiminin desteklenmesi, söz konusu kurak periyotlar için hem üretici hem de ülke ekonomisi açsından büyük önem arz etmektedir. Öte yandan ülkesel boyutta doğru tarımsal destek politikalarının olușturulması ve özelliklede su kaynağı sınırlııklarını da dikkate alan bir destek politikasının geliștirilmesi, sürdürülebilir üretim politikası için büyük önem arz etmektedir. Ayrıca, kurak dönemlerde ve sonrasında olușacak su krizine karșı gerekli önlemelerin alınması ve su yönetimi planlarının hazırlanması havza için hayati öneme sahiptir. Karar vericilerin söz konusu yașanacak kuraklıkların etkilerinin azaltılması bașta olmak üzere, sürdürülebilir canlı yașamı ve tarımsal üretim için gerekli iș ve ișlemleri gerçekleștirmesi için gerekli çalıșmaları bu günden bașlatması gerekmektedir.

Jeoistatistiksel yöntemde IDW metodu kullanılarak șiddet dağılım haritaları yapılmıștır. Havza içerisinde söz konusu tarımsal kurak devrelerin șiddetinin havza içerisinde nasıl bir dağılım gösterdiği ve ağırlıklı hangi bölgelerin ne șiddette etkileneceği saptanmıștır. Bu bilgiye bağlı olarakta alınması gereken önlemlerin düzeyi ve de ağırlığı bu bilgiler yardımıyla daha gerçekçi ve çözüm odaklı olabilir.

\section{KAYNAKLAR}

Ahrens B (2006). Distance in spatial interpolation of daily rain gauge data. Hydrology and Earth System Sciences, 10(2), 197- 208.

Anonim (2012). Faaliyet Raporu 2012. T.C. Orman ve Su 
İșleri Bakanlığı Devlet Su Ișleri Genel Müdürlüğü. Ankara.

Anonim (2019). Sektörel Su Tahsisi Eylem Planı ve Genelgesi (2019-2024). Konya Kapalı Havzası Sektörel Su Tahsis Planı Hazırlanması Projesi. T.C. Tarım ve Orman Bakanlığı Su Yönetimi Genel Müdürlüğü. Beștepe Mahallesi, Alparslan Türkeș Cad. No:71, Yenimahalle/Ankara

Aydın O, Çiçek i (2013). Ege bölgesindeki yağıșın mekânsal dağıımı. Coğrafi Bilimler Dergisi, 11 (2), 101-120.

Bașkan O (2004). Gölbası yöresi topraklarının mühendislik, fiziksel özellik ilișkilerinde jeoistatistik uygulaması, Doktora Tezi, AÜ, Fen Bilimleri Enstitüsü, (Basılmamıș) Ankara.

Delhomme JP (1978). Kriging in the Hydrosciences. Advances in Water Resources, 1 (5): 251-266.

Demircan M, Arabacı H, Gürkan H, Eskioğlu O, Coșkun M (2017). Climate Change Projections for Turkey: Three Models and Two Scenarios, Türkiye Su Bilimi ve Yönetimi Dergisi (Turkish Journal Of Water Science \& Management), ISSN:2536 474X Publication number:6777, Volume: 1 Issue: 1, January 2017, Ankara

FEMA (1995). National mitigation strategy. Federal Emergency Management Agency, Washington, DC.

Franke R, Nielson G (1980). Smooth interpolation of large sets of scattered data. International Journal for Numerical Methods in Engineering, 15, 1691-1704.

Goovaerts P (2000). Geostatistical approaches for incorporating elevation into the spatial interpolation of rainfall, Journal of Hydrology, 228, 113-129.

Gürler C (2017). Beyșehir ve Konya-Cumra-Karapınar Alt Havzalarında Standartlaștııılmıș İndis Yaklașımı İle Hidrolojik Kuraklık Değerlendirmesi. Uzmanlık Tezi. T.C. Orman ve Su İșleri Bakanlığı, Su Yönetimi Genel Müdürlüğü. Ankara

Isaaks EH, Srivastava RM (1989). An Introduction to applied geostatistics. Oxford University Press, New Yourk, p. 561

Kale MM (2018). Yeșilırmak Havzası Mekânsal Yağıș
Dağııımına ait Değișiminin Deterministik ve Stokastik Yöntemlerle Belirlenmesi. Yerbilimleri, 2018, 39 (3), 263-276.

Li J, Heap AD (2008). A Review of Spatial Interpolation Methods for Environmental Scientists. Geoscience Australia, Canberra, 2008.

McKee T, Doesken N, Kleist J (1993). The relationship of drought frequency and duration to time scale. Proceedings of the Eighth Conference on Applied Climatology (s. 179-184). Anaheim, California: American Meteorological Society.

Olea RA (1977). Measuring spatial dependence with semivariograms. kansas geological survey, series on spatial analysis, No. 3, Lawrance, Kansas. p. 122

Riebsame W.E., Changnon S.A., Karl T.R., 1991. Drought and Natural Resources Management in the United States: Impacts and Implications of the 1987-89 Drought. Westview Press, Boulder, CO.

Taș I, Kırnak H (2011). Yarı kurak iklim bölgelerinde bitki su tüketiminin tahmininde kullanılabilecek ampirik modeller. Adnan Menderes Üniversitesi, Ziraat Fakültesi Dergisi, 2011; $8(1): 57-66$.

Vieira SR, Hatfield JL, Nielsen DR, Biggar JW (1983). Geostatistical theory and application to variability of some agronomical properties. Hilgardia, 51 (3): 1-75, Davis- California

Wilhite D, Glantz M (1985). Understanding the drought phenomenon: the role of definitions. Water International (10), 111-120.

Wilhite DA, Svoboda MD, Hayes MJ (2005). Monitoring Drought in the United States: Status and Trends. Monitoring and Predicting. Agricultural Drought: A Global Study. Ed. Vijendra K. Boken, Arthur P. Cracknell, Ronald L. Heathcote. Published by Oxford University Press, Inc. 198 Madison Avenue, New York, New York 10016

WMO (2012). Standardized Precipitation Index User Guide. World Meteorological Organization. 